\title{
Influence of Pre Harvest and Pre Flower Sprays of Gibberellic acid, Napthalene acetic acid and Ethrel on Flowering Behaviour, Fruit Yield of Phalsa Cultivar Purple Round under Jammu- Sub Tropics
}

\author{
Kunzang Lamo*, Deep Ji Bhat, V.K. Wali, Parshant Bakshi, \\ Amit Jasrotia and Gagan Mehta
}

Department of Fruit Science, Skuast, Jammu, India

*Corresponding author

\begin{tabular}{|c|c|}
\hline & A B S T R A C T \\
\hline $\begin{array}{l}\text { K e y w o r d s } \\
\text { Phalsa, Purple } \\
\text { Round, Plant } \\
\text { growth regulators, } \\
\text { Flowering behavior } \\
\text { and yield. }\end{array}$ & \multirow{3}{*}{ 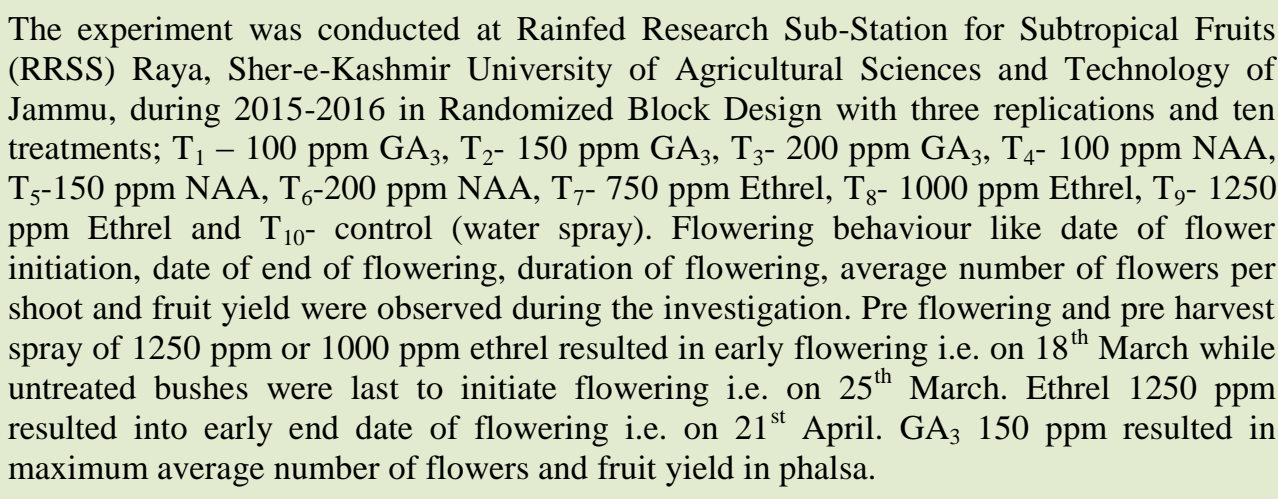 } \\
\hline Article Info & \\
\hline $\begin{array}{l}\text { Accepted: } \\
\text { 28 September } 2017 \\
\text { Available Online: } \\
10 \text { October } 2017\end{array}$ & \\
\hline
\end{tabular}

\section{Introduction}

Phalsa (Grewia asiatica L.) belongs to family Tiliaceae. The phalsa is indigenous to Indian sub-continent and South-East Asia (Chundawat and Singh, 1980). Phalsa is found in wild form all along the foothills of Himalayas. There are 18 genera and 400 species which are mostly distributed in tropical and sub-tropical regions of the world. The genus Grewia has 140 species, out of which 40 occur in India. Phalsa is sub-tropical fruit plant, flowering starts from FebruaryMarch. Phalsa bear flowers on current year growth in the axil of the leaves and the dehiscence of anther takes place before the flowers are completely open (Godara, 1985).
There are three to seven peduncles and each peduncle has three to six flowers of yellow colour. Phalsa is self-compatible, but pollens are not able to reach the stigma to effect the self-pollination due to detraction of stamens away from the stigma causes low fruit set (Randhawa and Dass, 1962). Phalsa fruit ripe in second fortnight of April and continue upto middle of June. Ripe berry contain 50-60 \% juice, $10-11 \%$ sugar and 2.0-2.5\% acid, 14.4 $\%$ carbohydrates, $1.5 \%$ protein, $0.9 \%$ fat, $129 \mathrm{mg} / 100 \mathrm{~g}$ of pulp, $89 \mathrm{mg}$ phosphorous, 3.1 $\mathrm{mg}$ iron, $22 \mathrm{mg} / 100 \mathrm{~g}$ of pulp vitamin $\mathrm{C}$ and 49 IU vitamin (Aykroyd, 1963). The fruit is non climacteric with extremely short shelf 
life. Inconsistent fruit yield, non-uniform ripening are the major bottlenecks in cultivation of phalsa. The use of plant growth regulators has become an important component of agrotechnical procedures for most of the cultivated plants and especially for fruit plants (Monselise, 1979). Plant growth regulators like $\mathrm{GA}_{3}$, NAA and ethrel has proved effective in increasing the size of fruit, improved fruit yield. The effect of plant growth regulators on growth and fruit yield of phalsa cv. Purple Round is a foregone conclusion, but the beneficial effect of plant growth regulators was yet to be fully explored especially in the Sub-Tropics of Jammu where phalsa bushes were successfully grown.

\section{Materials and Methods}

The present investigation entitled "Influence of Pre harvest and Pre flowering Sprays of Gibberellic acid, Napthalene acetic acid and Ethrel on flowering behaviour, fruit yield of phalsa cultivar Purple Round under JammuSuib tropics" was carried out at RRSS during the year 2015-16 on thirty years old, healthy phalsa bushes already established in the field. The bushes were pruned in mid of December. Geographically the experimental field is situated at an elevation of $332 \mathrm{~m}$ above mean sea level and lies at $32^{\circ} 39^{\prime}$ North latitude and $74^{\circ} 53^{\prime}$ East longitude. The treatments were imposed at two time's first spray of plant growth regulators was done at pre-flowering Stage and second spray was done at preharvesting stage. There were ten treatments; $\mathrm{T}_{1}-100$ ppm GA $3, \mathrm{~T}_{2}-150 \mathrm{ppm} \mathrm{GA}_{3}, \mathrm{~T}_{3}-200$ ppm $\mathrm{GA}_{3}, \mathrm{~T}_{4}-100$ ppm NAA, T -150 ppm NAA, $T_{6}-200$ ppm NAA, $T_{7-} 750$ ppm Ethrel, $\mathrm{T}_{8^{-}} 1000 \mathrm{ppm}$ Ethrel, $\mathrm{T}_{9}-1250 \mathrm{ppm}$ Ethrel and $\mathrm{T}_{10^{-}}$control (water spray). The observations were recorded for flowering behaviour like date of flower initiation, date of end of flowering, duration of flowering, average number of flowers per shoot and fruit yield were observed during the investigation.
The date of opening of first flower for each treatment was considered as the date of start of flowering. Observations were recorded regularly from tagged branches. End of flowering was recorded when almost all the flowers of bush were opened and there after no more flowering took place. The end of flowering i.e. petal fall was recorded in the field and the date recorded thereof. Duration of flowering was calculated by counting the total number of days from commencement of flowering to end of flowering. Four shoots in four directions (east, west, north and south) of all the treatments were tagged. The number of flowers of each treatment was determined on tagged shoots and expressed as number of flowers per shoot. The fruits harvested from each bush were weighed and considered as total yield and expressed in $\mathrm{kg}$ / bush.

\section{Results and Discussion}

Data recorded on flowering behaviour (date of flower initiation, date of end of flowering, duration of flowering, average number of flowers per shoot) and fruit yield of phalsa cv. Purple Round is given in (Table 1). The perusal of data presented in Table 1 revealed that flowering commenced earliest i.e. $18^{\text {th }}$ March in bushes treated with $1000 \mathrm{ppm}$ or $1250 \mathrm{ppm}$ ethrel. The untreated bushes were last to initiate flowering i.e. on $25^{\text {th }}$ March. The earliness in flowering is probably because the ethrel releases ethylene when come in contact with the plant tissue which in turn, triggers the shoots to flower early.

The earlier flowering in ethrel may be due to breaking of dormancy of buds and shoots. The reported results of floral induction as results of ethrel treatments to mango trees agreed with Chacko et al., (1972) and Rath and Das (1979). Similar effect of ethrel on induction of early flowering and initiation of full blooming (opening of flowers) had been reported in Langra mango by (Das et al., 1989), in guava (Brahmachari et al., 1996). 
The data regarding effect of plant growth regulators on date of end of flowering is presented in Table 1 indicate that among different treatments, the date of end of flowering was earlier in bushes treated with $1250 \mathrm{ppm}$ ethrel $\left(21^{\text {st }}\right.$ April), while it was prolonged $\left(9^{\text {th }}\right.$ May) in untreated bushes.

Ethylene increases the endogenous level of ethylene production in shoot apices and stimulate the formation of separation layer or abscission zones in flowers by stimulating the activity of hydrolases enzyme. The present observation are in conformity with the findings of (Hussain et al., 2008) in pineapple. The duration of flower in response to different growth regulator treatments is given in Table 1. The minimum duration of flower (35.90 days) was recorded with the application of $1250 \mathrm{ppm}$ and maximum duration of flower (46.00 days) was recorded in control treatment. The present observations are in line with the findings of Ghadage et al., (2016) in cashew.

Table.1 Effect of plant growth regulators on flowering behavior and fruit yield of phalsa cv. Purple Round

\begin{tabular}{|c|c|c|c|c|c|}
\hline Treatments & $\begin{array}{l}\text { Date of flower } \\
\text { initiation }\end{array}$ & $\begin{array}{c}\text { Date of } \\
\text { end of } \\
\text { flowering }\end{array}$ & $\begin{array}{l}\text { Durationof } \\
\text { flowering } \\
\text { (days) }\end{array}$ & $\begin{array}{c}\text { Average } \\
\text { number of } \\
\text { flowers per } \\
\text { shoot }\end{array}$ & $\begin{array}{c}\text { Yield } \\
\text { (kg/bush) }\end{array}$ \\
\hline$T_{1}(100$ ppm GA $)$ & $20^{\text {th }}$ March & $27^{\text {th }}$ April & 39.00 & 124.74 & 2.90 \\
\hline$T_{2}(150$ ppm GA $)$ & $20^{\text {th }}$ March & $26^{\text {th }}$ April & 38.50 & 128.83 & 3.00 \\
\hline$T_{3}(200$ ppm GA 3$)$ & $21^{\mathrm{st}}$ March & $29^{\text {th }}$ April & 40.00 & 121.25 & 2.78 \\
\hline $\mathrm{T}_{4}(100$ ppm NAA $)$ & $22^{\text {nd }}$ March & $6^{\text {th }}$ May & 45.55 & 123.12 & 2.75 \\
\hline$T_{5}(150$ ppm NAA $)$ & $21^{\text {st }}$ March & $2^{\text {nd }}$ May & 43.00 & 124.66 & 2.86 \\
\hline $\mathrm{T}_{6}(200 \mathrm{ppm}$ NAA $)$ & $23^{\text {rd }}$ March & $7^{\text {th }}$ May & 45.50 & 119.10 & 2.50 \\
\hline$T_{7}(750$ ppm Ethrel $)$ & $18^{\text {th }}$ March & $22^{\text {nd }}$ April & 36.50 & 112.08 & 2.18 \\
\hline$T_{8}(1000$ ppm Ethrel) & $18^{\text {th }}$ March & $22^{\text {nd }}$ April & 36.00 & 110.08 & 2.02 \\
\hline$T_{9}(1250$ ppm Ethrel) & $18^{\text {th }}$ March & $21^{\text {st }}$ April & 35.90 & 109.42 & 1.94 \\
\hline $\mathbf{T}_{10}$ (Control) & $25^{\text {th }}$ March & $9^{\text {th }}$ May & 46.00 & 106.33 & 1.88 \\
\hline C.D. $(p \leq 0.05)$ & & & 0.82 & 5.17 & 0.21 \\
\hline
\end{tabular}

It is obvious from the data given in Table 1 that the treatment $150 \mathrm{ppm} \mathrm{GA}_{3}$ resulted in maximum average number of flowers per shoot (128.83) which was statistically at par with $100 \mathrm{ppm} \mathrm{GA}_{3}$ (124.74) and $150 \mathrm{ppm}$ NAA (124.66). Whereas, minimum average number of flowers (106.33) were recorded in control treatment. The increase in number of flowers per shoot might be due to the effect of gibberellic acid in accelerating the differentiation of inflorescence and rapid elongation of peduncle, leading to full development of flower buds having functional reproductive parts (Ozgvuen and Kaska, 1990 and Parouissi et al., 2002). The result are in conformity with the findings of (Anwar et al., 1990) in strawberry, (Singh, 2006) in phalsa and (Lal et al., 2013) in mango.

It is clear from the data given in Table 1 that all growth regulator treatments except 1250 ppm and 1000 ppm ethrel effect in increasing the yield of phalsa crop as compared to control. Maximum fruit yield of $3.00 \mathrm{~kg} / \mathrm{bush}$ was recorded with $150 \mathrm{ppm} \mathrm{GA}_{3}$ which was statistically at par with 100 ppm $\mathrm{GA}_{3}(2.90$ $\mathrm{kg} /$ bush) and $150 \mathrm{ppm}$ NAA (2.86 kg/bush). Minimum fruit yield of $1.88 \mathrm{~kg} / \mathrm{bush}$ was 
recorded in control treatment. Among all the treatments $\mathrm{GA}_{3}$ recorded highest fruit yield, this might be due to increase in fruit set, large number of fruits, low percentage of fruit drop, more retention of fruits, better physiology of developing fruits in turn increased berry size, and berry weight. These results are in line with the findings (Randhawa et al., 1959; Singh et al., 1966; Reddy, 1977; Debnath et al., 2011; Singh et al., 2011 and Singh et al., 2017) in phalsa.

From the above studies it can be concluded that the application of ethrel resulted in earliest flowering, early end date of flowering and $\mathrm{GA}_{3} 150 \mathrm{ppm}$ resulted in maximum average number of flowers and fruit yield in phalsa.

\section{References}

Anwar, M., Hafiz, A. H. 1990. Effect of different concentrations of gibberellic acid on the growth and yield of strawberry. Sarhad Journal Agriculture, 6(1): 57-59.

Aykrowyd, W. R., (Eds.). 1963. The nutritive value of Indian foods and planning of satisfactory dites. pp 101-126. Indian Council of Medical Research, New Delhi.

Brahmachari, V. S., Mandal, A. K., Kumar, R. and Rani, R. 1996. Effect of growth substance on flowering and fruiting characters of Sardar guava (Psidium guajava L.). Horticulture Journal, 9(1): 1-7.

Chacko, E. K., Kohli, R. R. and Randhawa, G. S. 1972. Studies on the effect of 2chloroethyl phosphonic acid (ethrel) in mango. Indian Journal of Horticulture, 29: 1-4.

Chundawat, B. S., and Singh, R. 1980. Effect of growth regulators on phalsa (Grewia asiatica L.) growth and fruiting. Indian Journal of Horticulture, 37: 124-131.
Das, G. C., Sahoo, S. C. and Ray, D. P. 1989. Studies on effect of gibberellic acid and urea either alone or in combination on the growth and flowering behavior of some "on" and "off" year shoots in Langra mango. Acta Horticulturae, 231: 495-499.

Debnath, A., Vanajalatha, K., Momin, U. and Reddy, M. 2011. Effect of napthaleneacetic acid, gibberellic acid, kinetin and ethrel on yield and quality in phalsa (Grewia subinequalis D.C.). The Asian Journal of Horticulture, 6(2): 474-477.

Ghadage, V. R., Ahlawat, T. R., Chawla, S. L., Shah, N. I. and Ghadage, N. 2016. Effect of plant growth regulators on flowering behavior of cashew $\mathrm{cv}$. Vengurla-4 grown in the hilly tracts of South Gujarat. Journal of Applied and Natural Science, 8(1): 23 - 27.

Godara, N. R., 1985. Reported $3^{\text {rd }}$ National workshop on Arid Zone Fruit Research, Mahatma Phule Agricultural University, Rahuri.

Hussain, M. J., Ulla, M. A., Salim, M. M. R., Rahman, M. M. and Sarker, M. M. R. 2008. Effect of different application time of ethrel on offseason pineapple production. International Journal of Sustainable Crop Production, 3(6): 6871

Lal, N., Das, R. P. and Verma, L. K. 2013. Effect of plant growth regulators on flowering and fruit growth of guava (Psidium guajava L.) cv. Allahabad Safeda. The Asian Journal of Horticulture, 8(1): 54-56.

Monselise, S. P., 1979. The use of growth regulators in citriculture. Review of Scientific Horticulture, 11: 151-162.

Ozguven, A. I., and Kaska, N. 1990. The effect of gibberellic acid application on the yield and quality of strawberries grown in high tunnel. Acta Horticulturae, 19: 41-52. 
Parouissi, G., Voylatris, D. G. and Drogour, P. D. 2002. Growth, flowering and yield responses to gibberellic acid of strawberry grown under different environmental conditions. Scientia Horticulturae, 96: 103-113.

Randhawa, G. S., and Dass, H. C. 1962. Floral biology of phalsa (Grewia asiatica Linn.). Indian Journal of Horticulture, 19: 19-24.

Randhawa, G. S., Singh, J. P. and Khanna, S. S. 1959. Effect of giberellic acid and some other plant growth regulators on fruit set, total yield and quality of phalsa (Grewia asiatica L). Indian Journal of Horticulture, 16: 202-205.

Rath, S., and Das, G. C. 1979. Effect of ringing and growth retardants on growth and flowering of mango. Scientia Horticulturae. 10: 101-104.

Reddy, S. A., 1977. Studies on the action of gibberellic acid and naphthaleneacetic acid on fruit set, yield and quality of fruit of phalsa (Grewia asiatica L.). M.Sc. (Ag.). Thesis, Andhra Pradesh Agricultural University, Rajendranagar, Hydrabad.

Singh, B. A., Yadav, A. L. and Meena, A. K.
2017. Study on foliar feeding of gibberellic acid and naphthaleneacetic acid on vegetative growth and yield of phalsa (Grewia Subinaequalis D.C.). International Journal of Current Microbiology and Applied Sciences, 6(6): 768-775.

Singh, J. P., Kumar, S., Katiyar, P. N. and Dwivedi, A. K. 2011. Effect of calcium nitrate, gibberellic acid and ethrel on fruiting, ripening and chemical traits of phalsa (Grewia subinaequalis D.C.). Annals of Horticulture, 4(1): 72-76.

Singh, K. K., Nijjar, G. S. and Bhathal, G. S. 1966. Effect of gibberellic acid and 2, 4, 5-T on the fruit set, size and yield of phalsa. Agricultural Research Journal, 3: 286-290.

Singh, L., Singh, S. and Singh, B. 2006. Effect of pruning levels and growth regulators on vegetative and fruit characteristics of phalsa during summer and winter. Proceeding on National Symposium on Production, Utilization and Export of Underutilized Fruits with Commercial Potentialities. Bindhan Chandra Krishi Vishwavidyalaya, West Bengal, India.

\section{How to cite this article:}

Kunzang Lamo, Deep Ji Bhat, V.K. Wali, Parshant Bakshi, Amit Jasrotia and Gagan Mehta. 2017. Influence of Pre Harvest and Pre Flower Sprays of Gibberellic acid, Napthalene acetic acid and Ethrel on Flowering Behaviour, Fruit Yield of Phalsa Cultivar Purple Round under Jammu- Sub Tropics. Int.J.Curr.Microbiol.App.Sci. 6(10): 3504-3508.

doi: https://doi.org/10.20546/ijcmas.2017.610.413 